\title{
Preclinical evaluation of the antineoplastic action of 5-aza-2'-deoxycytidine and different histone deacetylase inhibitors on human Ewing's sarcoma cells
} Annie Hurtubise ${ }^{1}$, Mark L Bernstein ${ }^{2}$ and Richard L Momparler*1

Address: ${ }^{1}$ Département de pharmacologie, Université de Montréal, Centre de recherche pédiatrique, and Service d'hématologie-oncologie, Hôpital Sainte-Justine, 3175 Côte Sainte-Catherine, Montréal, Québec, H3T 1C5, Canada and 2 Hematology-Oncology, IWK Health Center and Dalhousie University, Halifax, Nova Scotia, Canada

Email: Annie Hurtubise - anniehurtubise@yahoo.ca; Mark L Bernstein - mark.bernstein@iwk.nshealth.ca; Richard L Momparler* - richard.l.momparler@umontreal.ca

* Corresponding author

Published: 17 November 2008

Cancer Cell International 2008, 8:16 doi:10.1 186/1475-2867-8-16

This article is available from: http://www.cancerci.com/content/8/I/16

(C) 2008 Hurtubise et al; licensee BioMed Central Ltd.

This is an Open Access article distributed under the terms of the Creative Commons Attribution License (http://creativecommons.org/licenses/by/2.0), which permits unrestricted use, distribution, and reproduction in any medium, provided the original work is properly cited.

\begin{abstract}
Background: Most patients with advanced Ewing's sarcoma (EWS) respond poorly to conventional chemotherapy, indicating the need for new treatment approaches. Epigenetic events, such as promoter hypermethylation and chromatin histone deacetylation, silence the expression of tumor suppressor genes (TSGs) and play an important role in tumorigenesis. These epigenetic changes can be reversed by using 5-aza-2'-deoxycytidine (5AZA-CdR), a potent inhibitor of DNA methylation, in combination with an inhibitor of histone deacetylase (HDAC).

Results: Here, we used a clonogenic assay to evaluate the in vitro antineoplastic activity of 5AZA$\mathrm{CdR}$ in combination with different HDAC inhibitors on EWS cells. We observed that the HDAC inhibitors, MS-275, trichostatin-A, phenylbutyrate, LAQ824 and depsipeptide, enhanced the antineoplastic action of 5AZA-CdR on EWS cells. The combination of 5AZA-CdR and MS-275 showed marked synergy, and was correlated with significant reactivation of the expression of two TSGs, E-cadherin and tumor suppressor lung cancer-I (TSLCI), in a EWS cell line.
\end{abstract}

Conclusion: These results suggest the value of future clinical studies investigating the combination of 5AZA-CdR and MS-275 in patients with advanced EWS.

\section{Background}

Metastatic or recurrent Ewing's sarcoma (EWS) does not respond well to standard chemotherapy [1], suggesting the need for new therapeutic approaches for the treatment of this malignancy. The silencing of tumor suppressor genes (TSGs) by aberrant DNA methylation plays an important role in tumorigenesis [2]. Since this epigenetic change is reversible, it is a potential target for chemotherapeutic intervention. 5-Aza-2'-deoxycytidine (Decitabine, Dacogen, 5AZA-CdR), a potent inhibitor of DNA methyl- ation, has been shown to reactivate the expression of silenced TSGs [3]. 5AZA-CdR has been approved for the treatment of hematological malignancies [4,5]. However, its antitumor activity is still under investigation. Certain genes that inhibit cellular growth can also be silenced by the deacetylation of chromatin-bound histones, which yields a compact chromatin configuration that is unfavorable for transcription [6]. Histone deacetylase (HDAC) inhibitors can reverse this process to produce an antitumor effect [7]. In addition to reactivation of genes that 
inhibit tumor growth, HDAC inhibitors can produce cell cycle arrest and induce apoptosis [8]. These inhibitors are currently under clinical investigation in patients with different types of malignancies [9].

Research has shown that the "cross-talk" between DNA methylation and histone modifications in chromatin can synergistically re-activate TSGs [10], suggesting that it might be useful to investigate the use of 5AZA-CdR in combination with HDAC inhibitors for tumor therapy. We previously reported that 5AZA-CdR plus depsipeptide (depsi) or phenylbutyrate (PB) showed synergistic antineoplastic action against breast carcinoma cells [11] and lung carcinoma cells [12], respectively. We also investigated the ability of 5AZA-CdR and MS-275 to reactivate two TSGs, E-cadherin (ECAD) [13] and tumor suppressor lung cancer-1 (TSCL1)[14], in EWS cells. Here, we evaluated the in vitro antineoplastic activity of 5AZA-CdR in combination with different HDAC inhibitors: depsi, $\mathrm{PB}$, trichostatin-A (TSA), LAQ824 (LAQ) and MS-275 in EWS cells. Our results revealed that all of the tested HDAC inhibitors enhanced the antineoplastic action of 5AZACdR on EWS cells.

\section{Methods \\ Material}

5AZA-CdR was obtained from Pharmachemie (Haarlem, Netherlands). Depsi (FR901228) was obtained from Fujisawa Pharmaceutical (Osaka, Japan). LAQ was kindly provided by Novartis Pharmaceuticals Inc. (East Hanover, NJ). TSA was obtained from Wako BioProducts (Richmond, VA). MS-275 was kindly provided by Schering AG (Berlin, Germany). PB was procured from Triple Crown America Inc. (Perkasie, PA). The human TC71 and TC32 EWS cell lines were kindly provided by Dr Jeffrey A. Toretsky (Lombardi Comprehensive Cancer Center, Georgetown University, Washington, DC). The cells were cultivated as monolayer in RPMI 1640 medium (Life Technologies, Burlington, Ontario) with $10 \%$ heat-inactivated fetal calf serum (Wisent, St-Bruno, Quebec) at $37^{\circ} \mathrm{C}$ with $5 \% \mathrm{CO}_{2}$ atmosphere.

\section{Clonogenic assay}

The loss of clonogenicity of TC71 and TC32 EWS cell lines was assessed after drug exposure by placing 100-250 cells in each well of a six-well $35 \mathrm{~mm}$ dish. The next day different concentrations of 5AZA-CdR and/or HDAC inhibitors: depsi, TSA, PB, MS-275 or LAQ were added at indicated concentrations for $48 \mathrm{~h}$. The cells were washed with drug-free medium and were incubated for an additional 7-11 days and then stained with $0.5 \%$ methylene blue in $50 \%$ methanol. The colonies (> 500 cells) were counted.
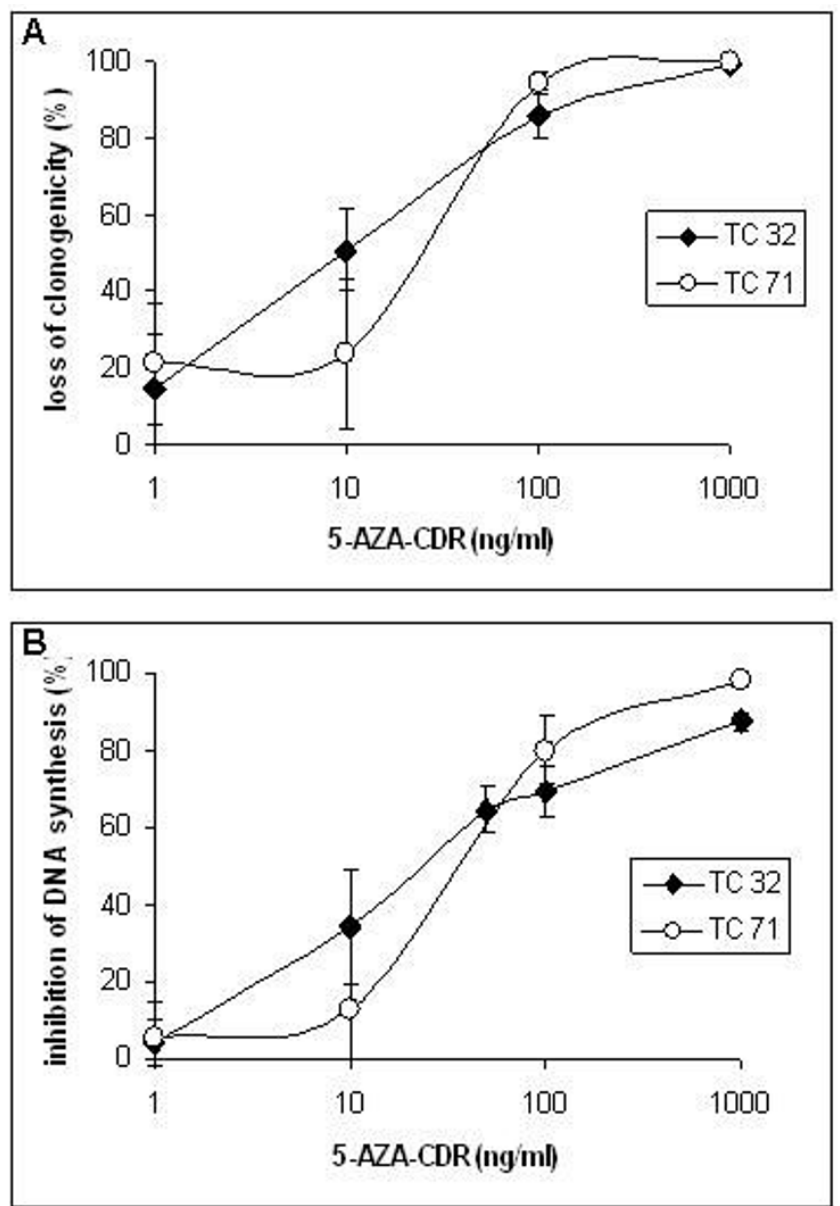

Figure I

Effect of different concentrations of 5AZA-CdR for $48 \mathrm{~h}$ exposure on loss of clonogenicity $(A)$ and for 72 $h$ exposure on inhibition of DNA synthesis (B) for TC32 and TC7I EWS cells. Data shown are mean values \pm S.D., $\mathrm{n} \geq 3$.

\section{Inhibition of DNA synthesis assay}

The inhibition of DNA synthesis by 5AZA-CdR and/or HDAC inhibitors was measured by the incorporation of radioactive thymidine into DNA. Aliquots of $\sim 10^{4}$ cells in $2 \mathrm{ml}$ of medium were placed in each well of a six-well 35 $\mathrm{mm}$ dish. The next day, the cells were exposed to the different concentrations of 5AZA-CdR and/or HDAC inhibitors as indicated above. Then, at $48 \mathrm{~h}, 0.5 \mu \mathrm{Ci}$ of radioactive tritium-labeled thymidine $(6.7 \mathrm{Ci} / \mathrm{mmol}$, ICN Biomedicals, Irvine, CA) was added to the medium for an additional $24 \mathrm{~h}$. The cells were then trypsinised, suspended in $0.9 \% \mathrm{NaCl}$, placed on a GF/C $25 \mathrm{~mm}$ glass fiber filter disc, washed with cold $0.9 \% \mathrm{NaCl}, 5 \%$ cold trichloroacetic acid and ethanol. The filters were dried, placed in EcoLite scintillation fluid (ICN Biomedicals) and the radioactivity was measured with a scintillation counter. 
Loss of clonogenicity(\%)

TC 32: $\bullet$ TC 71: O
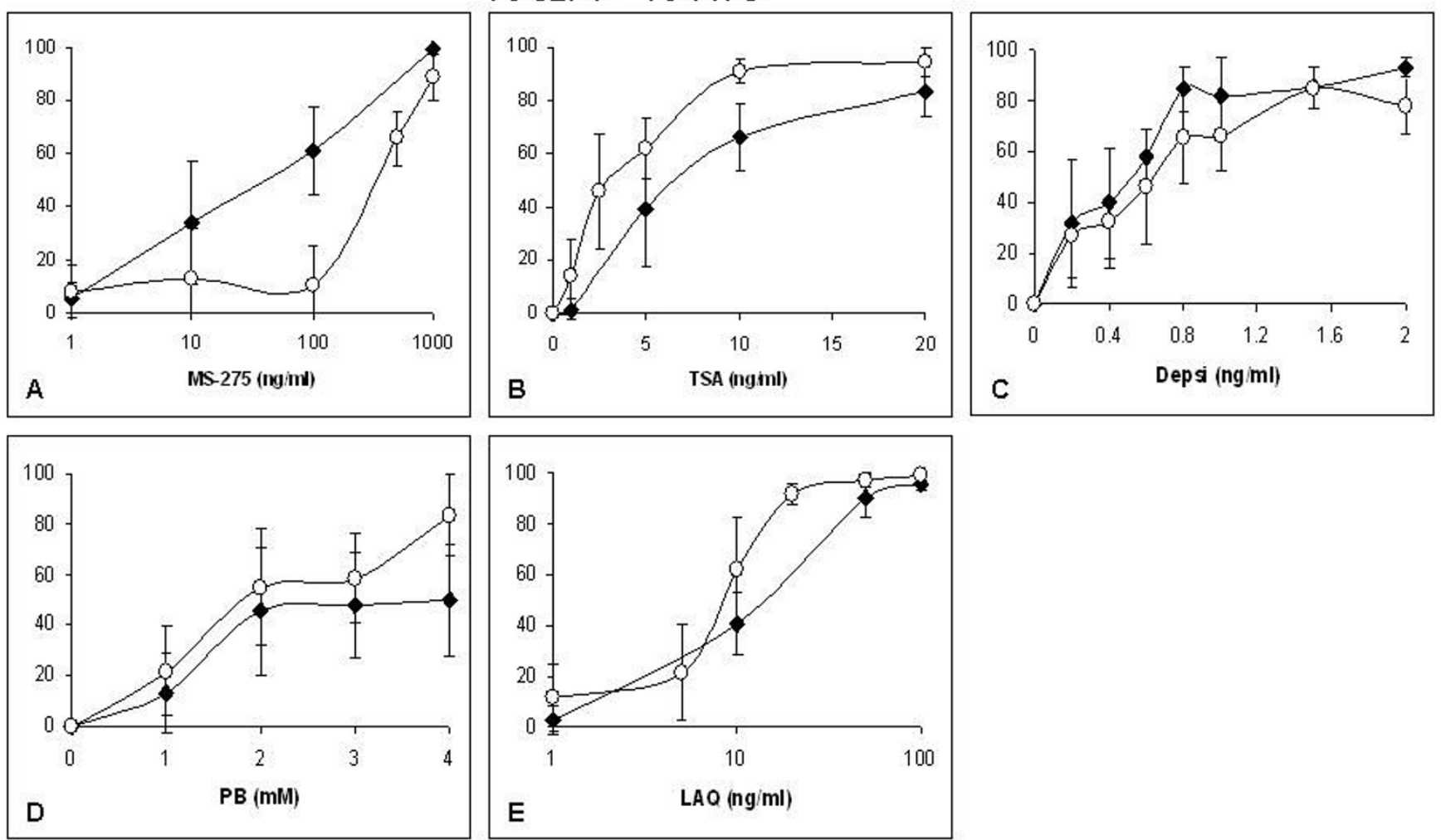

Figure 2

Effect of different concentrations of HDAC inhibitors for $48 \mathrm{~h}$ exposures on loss of clonogenicity for TC32 and TC7I EWS cells. Data shown are mean values \pm S.D., $n \geq 3$.

\section{Isolation of RNA and RT-PCR analysis}

In order to study the reactivation of gene in EWS cell lines, we treated cells with 5AZA-CdR $(100 \mathrm{ng} / \mathrm{ml})$ and/or MS$275(250 \mathrm{ng} / \mathrm{ml})$ for $72 \mathrm{~h}$. Cells were harvested $24 \mathrm{~h}$ after the removal of the drugs and total RNA was isolated using RNeasy Mini Kit (Qiagen, Mississauga, Ontario). For cDNA synthesis, total RNA was reverse-transcribed using OmniScript RT kit (Qiagen). The reaction was performed at $37^{\circ} \mathrm{C}$ for $1 \mathrm{~h}$ followed by $5 \mathrm{~min}$ at $93^{\circ} \mathrm{C}$ to inactivate the enzyme. PCR amplifications were performed using HotStar Taq Polymerase (Qiagen) and specific primers spanning different exons for ECAD, TSLC1 and 18S ribosomal RNA. For ECAD (GenBank NM 004360), the primers were sense 5'-CAATCCCACC ACGTACAAG-3' and antisense 5'-CTGGGCAGTGTAGGATGTGA-3'. The length of the PCR product of ECAD was $410 \mathrm{bp}$. For TSLC1 (GenBankNM 014333), the primers were sense 5'GGGCAGAATCTGTTTA CGAAAGA-3' and antisense 5'TCGGTATAGAGCTGGCAAAAGTA-3'. The length of the PCR product of TSLC1 was $257 \mathrm{bp}$. The human 18S ribosomal RNA gene (GenBank X03205) was amplified as an internal control using as sense primer 5'-TCGATGGTAG
TCGCCGTGCCTA-3' and antisense 5'-CTGCTGCCTTCCTTGGATGTGGTA-3'. The length of the PCR product of $18 \mathrm{~S}$ ribosomal RNA was $110 \mathrm{bp}$. Samples were amplified in a thermocycler under the following conditions. For ECAD, the PCR conditions were $5 \mathrm{~min}$ at $95^{\circ} \mathrm{C}, 15 \mathrm{~s}$ at $94^{\circ} \mathrm{C}, 15 \mathrm{~s}$ at $58^{\circ} \mathrm{C}$ and $15 \mathrm{~s}$ at $72^{\circ} \mathrm{C}$, for 5 cycles. Then, the annealing temperature was lowered at $56^{\circ} \mathrm{C}$ for 35 more cycles. For TSLC1, the PCR conditions were $5 \mathrm{~min}$ at $95^{\circ} \mathrm{C}, 30 \mathrm{~s}$ at $94^{\circ} \mathrm{C}, 15 \mathrm{~s}$ at $56^{\circ} \mathrm{C}$ and $15 \mathrm{~s}$ at $72^{\circ} \mathrm{C}$, for 5 cycles. Then, the annealing temperature was lowered at $54^{\circ} \mathrm{C}$ for 34 more cycles. For $18 \mathrm{~S}$ ribosomal RNA, the PCR conditions were $5 \mathrm{~min}$ at $95^{\circ} \mathrm{C}, 45 \mathrm{~s}$ at $94^{\circ} \mathrm{C}, 30 \mathrm{~s}$ at $60^{\circ} \mathrm{C}$ and $30 \mathrm{~s}$ at $72^{\circ} \mathrm{C}$, for 5 cycles. Then, the annealing temperature was lowered at $58^{\circ} \mathrm{C}$ for 11 more cycles. For each gene, the number of cycle chosen as to be in the exponential phase of DNA amplification. The PCR products were electrophoresed on 2\% agarose gel and detected by ethidium bromide staining. The measurement of the absolute concentration of amplified DNA was obtained with the Agilent 2100 Bioanalyzer (Agilent Technologies, Palo Alto, CA) as described previously.[11] This latter method, which is very sensitive, uses capillary electrophoresis and 
Inhibition of DNA synthesis (\%)

TC 32: $\diamond$ TC 71:O
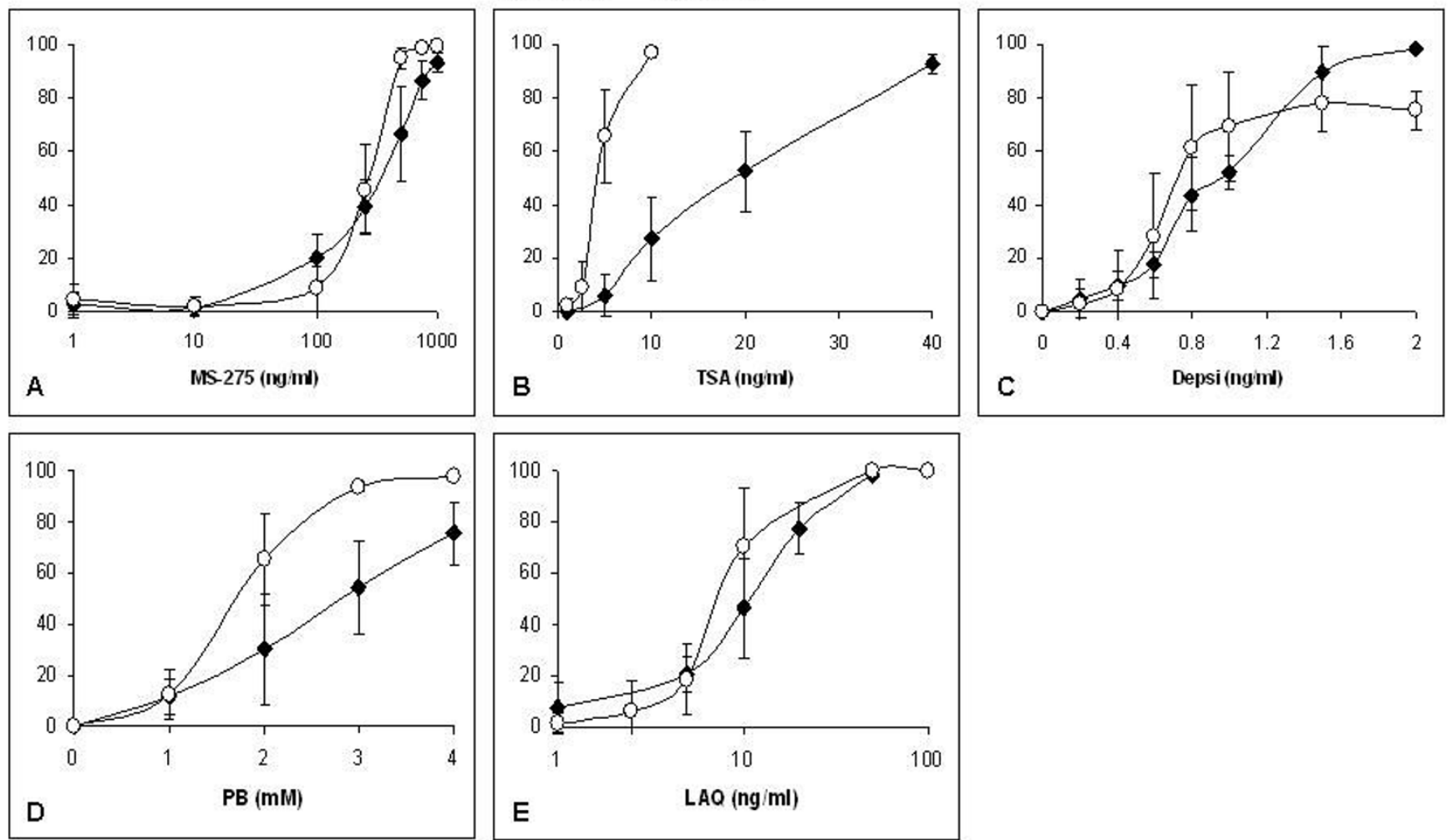

Figure 3

Effect of different concentrations of HDAC inhibitors for 72 exposures on inhibition of DNA synthesis for TC32 and TC7 I EWS cells. Data shown are mean values \pm S.D., $n \geq 3$.

fluorescent detection to measure both the size and quantity of DNA.

\section{Data analysis}

The data are the mean values \pm SD for $n \geq 3$. Differences between groups were analyzed using one-way ANOVA test coupled with a Tukey-Kramer test, by comparing the result of each drug alone with the results of the combination of both agents. The critical level of significance was set at $\mathrm{p} \leq$ 0.05 .

\section{Results}

The effects of different concentrations of 5AZA-CdR on loss of clonogenicity and on the inhibition of DNA synthesis in TC71 and TC32 EWS cell lines are shown in Figure $1 \mathrm{~A}$ and $1 \mathrm{~B}$, respectively. The concentration of 5AZACdR that produced about $50 \%$ loss of clonogenicity $\left(\mathrm{IC}_{50}\right)$ following a $48 \mathrm{~h}$ exposure was in the range of $10 \mathrm{ng} / \mathrm{ml}$ for the TC32 cell line and $30 \mathrm{ng} / \mathrm{ml}$ for the TC71 cell line. The $\mathrm{IC}_{50}$ values for inhibition of DNA synthesis following a 72 $\mathrm{h}$ exposure of 5AZA-CdR were in the same range as the $\mathrm{IC}_{50}$ values for loss of clonogenicity for both ES cell lines.

For the HDAC inhibitors, the $\mathrm{IC}_{50}$ values for loss of clonogenicity for the TC32 and TC71 cell lines, respectively, were: 30 and $400 \mathrm{ng} / \mathrm{ml}$ for MS-275 (Figure 2A), 7 and $2 \mathrm{ng} / \mathrm{ml}$ for TSA (Figure 2B), 0.5 and $0.6 \mathrm{ng} / \mathrm{ml}$ for depsi (Figure 2C), 2 mM for PB (Figure 2D) and $\sim 12$ and $8 \mathrm{ng} /$ $\mathrm{ml}$, for LAQ (Figure 2E). For the inhibition of DNA synthesis the $\mathrm{IC}_{50}$ values for the HDAC inhibitors for the TC32 and TC71 cell lines, respectively, were: $\sim 400 \mathrm{ng} / \mathrm{ml}$ for MS-275 (Figure 3A), 20 and $2 \mathrm{ng} / \mathrm{ml}$ for TSA (Figure $3 \mathrm{~B}), \sim 1$ and $0.8 \mathrm{ng} / \mathrm{ml}$ for depsi (Figure 3C), 3 and $2 \mathrm{mM}$ for $\mathrm{PB}$ (Figure 3D) and $\sim 10$ and $8 \mathrm{ng} / \mathrm{ml}$ for LAQ (Figure $3 \mathrm{E})$.

The objective of this study was to determine if 5AZA-CdR in combination with HDAC inhibitors would show enhanced antineoplastic activity against the EWS cells. In our clonogenic assay 5AZA-CdR plus the HDAC inhibitors TSA, PB, LAQ, depsi and MS-275 showed a significant 

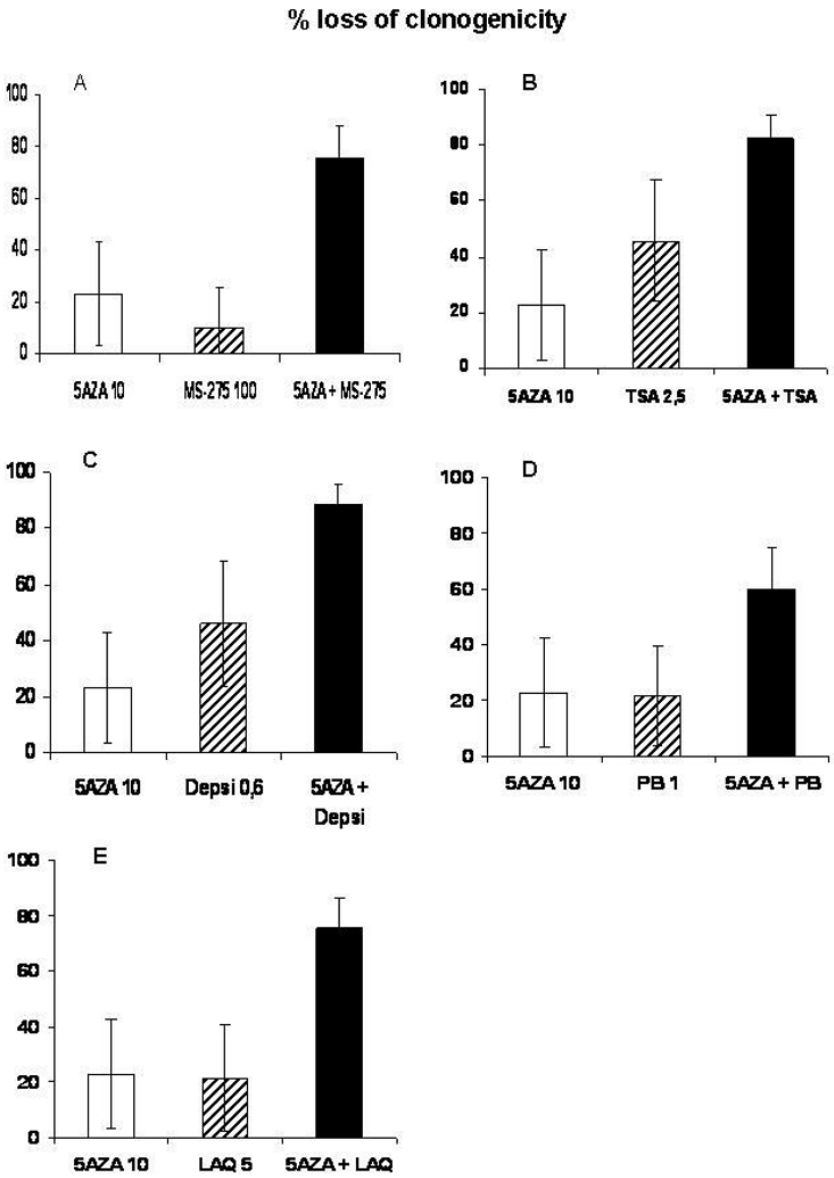

Figure 4

Effect of $48 \mathrm{~h}$ exposure of 5AZA-CdR (5AZA) ( $10 \mathrm{ng} /$ $\mathrm{ml}$ ) and/or HDAC inhibitors on loss of clonogenicity of TC7 I EWS cells. A) MS-275 (I00 ng/ml), B) TSA $(2.5$ $\mathrm{ng} / \mathrm{ml})$, C) Depsi $(0.6 \mathrm{ng} / \mathrm{ml})$, D) PB (I mM), E) LAQ (5 ng/ $\mathrm{ml})$. Data shown are mean values \pm S.D., $n \geq 3$. Statistical analysis: 5AZA + HDAC inhibitor $>$ 5AZA or HDAC inhibitor $\mathrm{p}<0.01$.

enhancement of their antineoplastic effect as compared to each agent alone $(\mathrm{p}<0.01)$ for the TC71 EWS cells (Figure 4). A clear synergistic interaction was observed between 5AZA-CdR and MS-275 or LAQ as defined by Valeriote and Lin [15].

The antineoplastic activity of 5AZA-CdR is related to its reactivation of TSGs silenced by aberrant methylation. Since the combination of 5AZA-CdR and MS-275 produced the most potent synergistic antineoplastic interaction on the TC71 EWS cells, we investigated their reactivation of the TSGs, ECAD and TSLC1 in this cell line (Figure 5). We observed that the combination of 5AZACdR and MS-275 produced a synergistic reactivation of the expression of these genes as compared to either agent alone.

\section{Discussion}

There is an urgent need to develop new approaches for the chemotherapy of advanced EWS. The inhibitor of DNA methylation, 5AZA-CdR, is an interesting agent to investigate for tumor therapy, since it can reactivate silenced TSGs [3]. This epigenetic agent has proven effective in patients with hematological malignancies $[4,5]$, and has shown some promising activity in patients with advanced lung cancer [16]. The HDAC inhibitors are another class of epigenetic agents that are of interest in the context of cancer therapy. These inhibitors convert chromatin to an open, transcription-facilitating conformation [6], and have been shown to have diverse actions on tumor cells, including activation of growth-inhibiting genes, induction of apoptosis, inhibition of cell cycle progression, and inhibition of human tumor xenografts in nude mice $[8,17,18]$. Several HDAC inhibitors are currently under clinical investigation in patients with solid tumors [9].

In this study, we first evaluated the single-agent antineoplastic action of 5AZA-CdR and five different HDAC inhibitors on human TC71 and TC32 EWS cell lines. In assays on loss of clonogenicity and inhibition of DNA synthesis, we observed good dose-response curves with 5AZA-CdR and all of the HDAC inhibitors. Both classes of epigenetic agents showed potential as single agents for the treatment of EWS.

Since a landmark study showed that an inhibitor of DNA methylation in combination with an HDAC inhibitor produced a synergistic reactivation of TSGs in neoplastic cells [10], we next investigated whether 5AZA-CdR in combination with HDAC inhibitors produces an additive or synergistic antineoplastic effect on EWS cells. In the clonogenic assay, we observed that 5AZA-CdR in combination with different HDAC inhibitors (TSA, LAQ, PB, Depsi and MS-275) produced an additive or synergistic antineoplastic interaction against TC71 EWS cells. We previously reported a synergistic antineoplastic interaction between 5AZA-CdR and some of these HDAC inhibitors for breast and lung tumor cell lines $[11,12]$.

\section{Conclusion}

In particular, the combination of 5AZA-CdR and MS-275 showed a marked synergistic interaction with respect to antineoplastic activity against EWS cells. This combination also produced a synergistic reactivation of two TSGs: ECAD and TSLC1. A previous report showed that MS-275 has significant in vitro and in vivo antitumor activity against EWS $[17,18]$, and MS-275 showed promising results in a phase I study on patients with EWS [19]. These previous findings and our present results combine to sug- 


\section{Expression of ECAD}

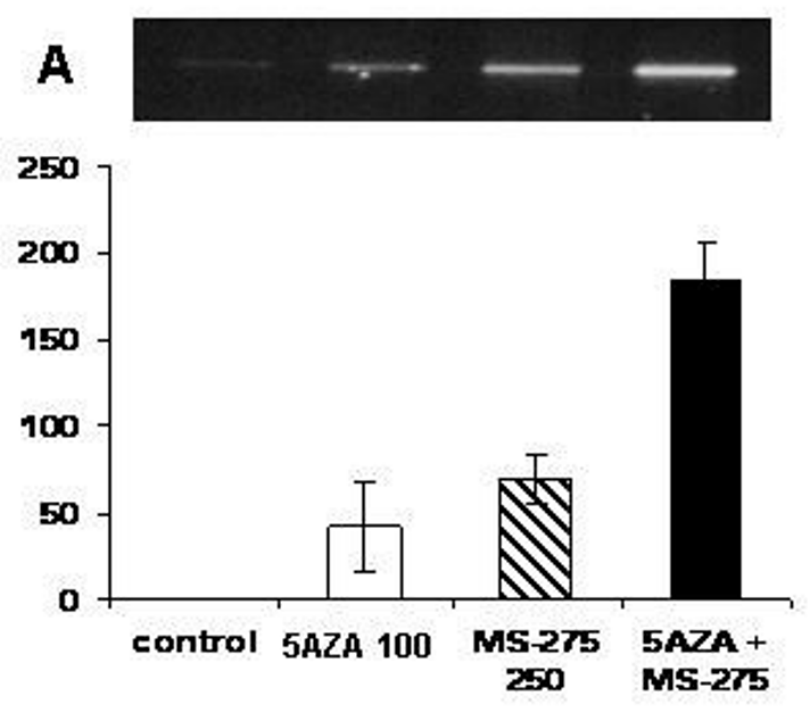

\section{Expression of TSLC1}

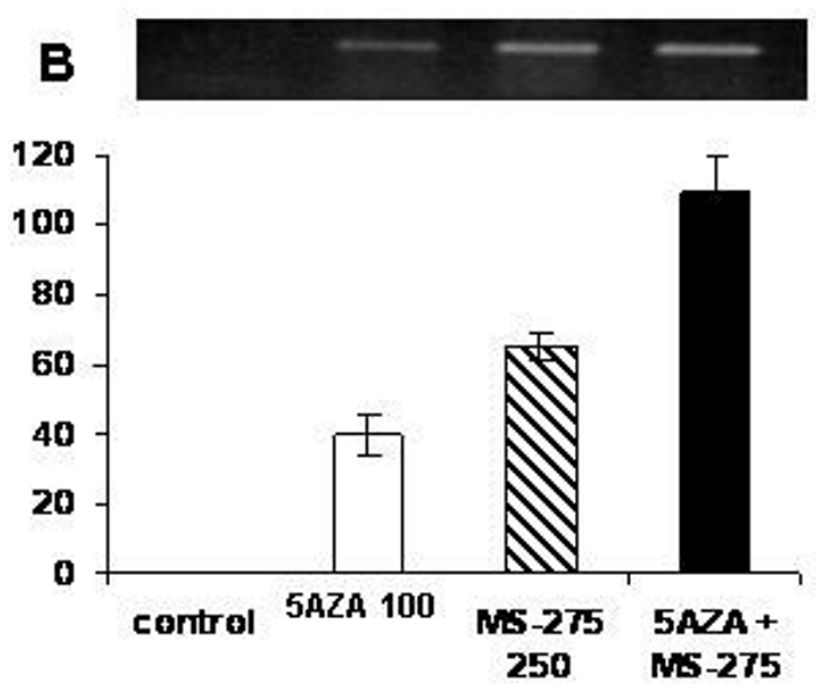

Figure 5

Effect of 5AZA-CdR (5AZA) ( $100 \mathrm{ng} / \mathrm{ml})$ and/or MS-275 (I00 $\mathrm{ng} / \mathrm{ml})$ after $72 \mathrm{~h}$ exposure on the induction of expression of ECAD (A) and TSLCI (B) in TC7 I EWS cells as determined by RT-PCR. The amplified cDNA was analyzed by electrophoresis on agarose (top) and quantitated by Agilent Bioanalyzer 2100 (bottom). The cDNA of I8S ribosomal RNA was used as an internal standard. Vertical axis values are for relative expression. Data shown are mean values \pm S.D, $\mathrm{n} \geq 3$. Statistical analysis for $(A)$ and $(B): 5 A Z A$ or $M S-275$ versus 5AZA + MS-275: $p<0.01$.

gest that 5AZA-CdR and MS-275 may be a good combination of epigenetic agents to investigate in patients with advanced

EWS.

\section{Competing interests}

The authors declare that they have no competing interests.

\section{Authors' contributions}

AH planned, performed the experimental work and wrote the manuscript. RLM planned the experimental work, evaluated the data and revised the manuscript. MLB evaluated the data and revised the manuscript.

\section{Acknowledgements}

This study was supported by a grant from the Canadian Cancer Society (RLM \#014193). AH is supported by a studentship from the Fonds de la recherche en santé du Québec.

\section{References}

I. Bernstein M, Kovar H, Paulussen M, Randall RL, Schuck A, Teot LA, Juergens $H$ : Ewing's sarcoma family of tumors: current management. Oncologist 2006, I I:503-519.

2. Jones PA, Baylin S: The fundamental role of epigenetic events in cancer. Nat Rev Genet 2002, 3:4I5-28.

3. Momparler RL: Pharmacology of 5-Aza-2'-deoxycytidine (decitabine). Semin Hematol 2005, 42:S9-16.

4. Issa JP, Issa JP, Garcia-Manero G, Giles FJ, Mannari R, Thomas D, Faderl S, Bayar E, Lyons J, Rosenfeld CS, Cortes J, Kantarjian HM: Phase
I study of low-dose prolonged exposure schedules of the hypomethylating agent 5-aza-2'-deoxycytidine (decitabine) in hematopoietic malignancies. Blood 2004, I 03: I 635-I640.

5. Lübbert M, Wijermans P, Kunzmann R, Verhoef G, Bosly A, Ravoet $C$, Andre $M$, Ferrant A: Cytogenetic responses in high-risk myelodysplastic syndrome following low-dose treatment with the DNA methylation inhibitor 5-aza-2'-deoxycytidine. $\mathrm{Br} J$ Haematol 200I, I I 4:349-357.

6. Marks P, Rifkind RA, Richon VM, Breslow R, Miller T, Kelly WK: Histone deacetylases and cancer: Causes and therapies. Nat Rev Cancer 2001, I: I94-202.

7. Conley BA, Wright J, Kummar S: Targeting epigenetic abnormalities with histone deacetylase inhibitors. Cancer 2006, I 07:832-840.

8. Peart MJ, Tainton KM, Ruefli AA, Dear AE, Sedelies KA, O'Reilly LA Waterhouse NJ, Trapani JA, Johnstone RW: Novel mechanisms of apoptosis induced by histone deacetylase inhibitors. Cancer Res 2003, 63:4460-447I.

9. Drummond DC, Noble CO, Kirpotin DB, Guo Z, Scott GK, Benz CC: Clinical development of histone deacetylase inhibitors as anticancer agents. Annu Rev Pharmacol Toxicol 2005, 45:495-528.

10. Cameron EE, Bachman KE, Myohanen S, Herman JG, Baylin SB: Synergy of demethylation and histone deacetylase inhibition in the re-expression of genes silenced in cancer. Nat Genet 1999, 21:103-107.

II. Primeau M, Gagnon J, Momparler RL: Synergistic antineoplastic action of DNA methylation inhibitor 5-aza-2'-deoxycytidine and histone deacetylase inhibitor depsipeptide on human breast carcinoma cells. Intl J Cancer 2003, I03:I77-I 84.

12. Boivin A-J, Momparler LF, Hurtubise A, Momparler RL: Antineoplastic action of 5-aza-2'-deoxycytidine and phenylbutyrate on human lung carcinoma cells. Anti-Cancer Drugs 2002, I 3:869-874.

13. Nam JS, Ino Y, Kanai Y, Sakamoto M, Hirohashi S: 5-aza-2'-deoxycytidine restores the E-cadherin system in E-cadherin- 
silenced cancer cells and reduces cancer metastasis. Clin Exp Metastasis 2004, $21: 49-56$.

14. Hui AB, Lo KW, Kwong J, Lam EC, Chan SY, Chow LS, Chan AS, Teo PM, Huang DP: Epigenetic inactivation of TSLCI gene in nasopharyngeal carcinoma. Mol Carcinog 2003, 38: I70-i 78.

15. Valeriote F, Lin H: Synergistic interaction of anticancer agents: a cellular perspective. Cancer Chemother Rep 1975, 59:895-900.

16. Momparler RL, Ayoub J: Potential of 5-aza-2'-deoxycytidine (Decitabine) a potent inhibitor of DNA methylation for therapy of advanced non-small cell lung cancer. Lung Cancer 200I, 34:SIII-II5.

17. Jaboin J, Wild J, Hamidi H, Khanna C, Kim CJ, Robey R, Bates SE, Thiele CJ: MS-27-275, an inhibitor of histone deacetylase, has marked in vitro and in vivo antitumor activity against pediatric solid tumors. Cancer Res 2002, 62:6108-60I5.

18. Eyüpoglu IY, Hahnen E, Tränkle C, Savaskan NE, Siebzehnrübl FA, Buslei R, Lemke D, Wick W, Fahlbusch R, Blümcke I: Experimental therapy of malignant gliomas using the inhibitor of histone deacetylase MS-275. Mol Cancer Ther 2006, 5:I248-I255.

19. Kummar S, Gutierrez M, Gardner ER, Donovan E, Hwang K, Chung EJ, Lee MJ, Maynard K, Kalnitskiy M, Chen A, Melillo G, Ryan QC, Conley B, Figg WD, Trepel JB, Zwiebel J, Doroshow JH, Murgo AJ: Phase I trial of MS-275, a histone deacetylase inhibitor, administered weekly in refractory solid tumors and lymphoid malignancies. Clin Cancer Res 2007, I3:541 I-54I7.

Publish with Bio Med Central and every scientist can read your work free of charge

"BioMed Central will be the most significant development for disseminating the results of biomedical research in our lifetime. "

Sir Paul Nurse, Cancer Research UK

Your research papers will be:

- available free of charge to the entire biomedical community

- peer reviewed and published immediately upon acceptance

- cited in PubMed and archived on PubMed Central

- yours - you keep the copyright 